\title{
MIR198 wt Allele
}

National Cancer Institute

\section{Source}

National Cancer Institute. MIR198 wt Allele. NCI Thesaurus. Code C82152.

The human MIR198 wild-type allele is located in the vicinity of 3q13.33 and is approximately 61 bases in length. This allele, which encodes MIR198 pre-miRNA, plays a role in the regulation of gene expression. Alteration in the expression of this gene is associated with development of schizophrenia. 